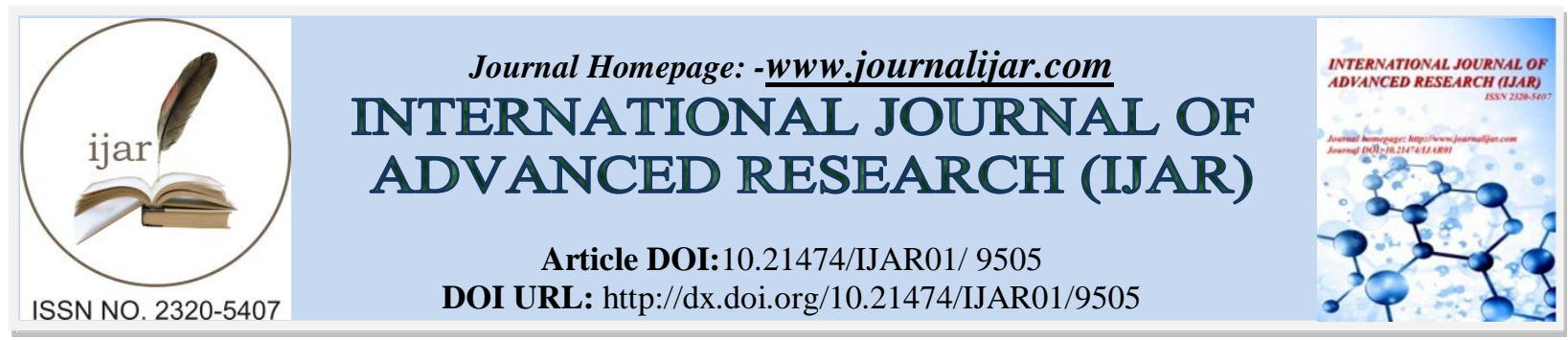

RESEARCH ARTICLE

\title{
PLANT RESPONSE OF CITRONELLA GRASS (ANDROPOGON NARDUS L.) TO SEVERAL MANURE APPLICATION AND PLANTING MEDIUM COMPOSITION.
}

Indra Dwipa ${ }^{1}$, Hestiamelia ${ }^{2}$ and Reni Mayerni ${ }^{1}$.

1. Lecturer, Departemnt of Agronomy, Faculty of Agriculture, Andalas University, Padang, West Sumatera, Indonesia.

2. Student, Departemnt of Agronomy, Faculty of Agriculture, Andalas University, Padang, West Sumatera, Indonesia.

\section{Manuscript Info}

(........................

Manuscript History

Received: 06 June 2019

Final Accepted: 08 July 2019

Published: August 2019

Key words:-

Citronella grass, manure, planting media.

\section{Abstract}

Manure has many advantages in improving soil texture and structure. The composition of plant media is ratio between soil weight and manure in planting medium. The research aimed to study the interaction manure and planting medium composition to growth and yield of citronella grass. The research was conducted in shade net house of Faculty of Agriculture, Andalas University, Padang, West Sumatera, Indonesia from August 2018 to January 2019. Completely randomized design was used (CDR) that consisted of 2 factors was used in the reserach. The first factor was type of manure (chicken, goat and cattle) and second factor was planting medium composition (ratio of soil weight and manure, 1:1, 1:2 and 1:3). The treatments were replied 3 times and for each experimetnal unit was consisted of 5 plants. The data was analysed by Duncan's New Multiple Range Test (DNMRT) in $5 \%$.The result showed that the ratio 1:2 affected dry weight of root. The beast manure application for growth and yield of citronella grass was $2.5 \mathrm{~kg} /$ polybag. The best composition of planting medium to cintronella grass was 1:3 for dry weight of root

Copy Right, IJAR, 2019,. All rights reserved.

\section{Introduction:-}

Citronella grass (Andopogon nardus L.) is a plant grass that produces essential oil from Graminae [1]. This plant is different from lemongrass which has its stem can be used as spice and for citronella grass, its leaves produce essential oil. Citronella grass contains citronella oil (Citronella and that can be used as perfum and cosmetic materials and geraniol. Citronella oil also can be used as insecticide, nematicide, anti fungi, anti bacterial and anti post-harvest pests [2].

Business opportunity of citronella grass is widely opened and it can be developed in Indonesia. The multiple function plant can be harvested many times and it is perennial plant and produce in every 4 years. In order to keep producing and the plant can growth optimally, the loose and fertile soil are required to increase growth and yield of plant. This plant can be integrated to palm oil plant. This plant can be used as intercropped plant in palm oil plantation [3].

\section{Corresponding Author:-Indra Dwipa.}

Address:-Lecturer, Departemnt of Agronomy, Faculty of Agriculture, Andalas University, Padang, West Sumatera, Indonesia. 
This commodity playes a significant role for foreign exchange, farmer income and employments. Essential oils from distillation result of citronella grass are cosmetic materials, soap, disinfectant, perfume, botanical pesticide, even fuel and medicine [4]. According to Indonesian Standard no 06-3953-1995, export requirement of Indonesian citronella oil is genariol content should be $85 \%$ in minimal, citronelal $35 \%$ in minimal and no another materials. This requirement can be fulfilled from planting to marketing. Rendemen quality of soil can be obtained by fertilizer application to increase optimal growth [5].

The problem that is faced by Indonesia in citronella grass development is low handling agronomy management such as various soil cultivation, un-uniform plant material, unappropriate type of citronella grass and fertilizer. The citronella grass is a plant that can grow optimal in fertile soil. Marginal land that has not been used for cultivation can be used as citrronell grass cultivation. One of marginal land is Ultisol soil. By the width, ultisol is potential land for agricultural development. However, many problems if this land is used for agricultural land such as low organic material content, low macro and $\mathrm{P}$ availability [6].

Manure is a material that can improve physic, biology and chimical of soil, soil characteristics to increase plant productivity. One of organic material can be used for this purpose is manure [7]. Generally, organic material plays role as soil material improver. The advantage of manure is it contains high nitrogen content that beneficial for plant growth and leaves. Many farms in Indonesia can support manure for material organic source.

The organic material that is easy to obtain such as chicken, cattle and goat. The chicken manure contained high nutrient content so that it stimulated plant vegetation to grow faster. $\mathrm{N}$ could increase chlorophyll formation so that photosynthesis activity increased and affected the plant growth. The cattle manure contained essential nutrients such as N, P and K. Goat manure could increase soil fertile, improve soil structure by soil aggregate formation, aeration and water holding power and cation exchange capasity. The interaction of ratio of planting medium and manure (1:1) and dose of NPKMg affected the leaf width of palm oil plant [8]. The ratio of soil and manure (1:3) affected number of leaves and length of root of mangosteen in 5 months after palnting [9]. The research aimed to study the interaction between manure and planting medium composition to growth and yield of citronella grass.

\section{Research Method:-}

The reserach was conducted in shade net house and Laboratory of Physiology, Faculty of Agriculture, Andalas University, Padang, Indonesia from August 2018 t0 January 2019. The altitude of experimental place was \pm 250 above sea level (asl). Completely randomized design (CDR) with 2 factors was used in this research. The first factor was manure with 3 treatments :

$\begin{array}{ll}\text { A1 } & \text { : chicken manure } \\ \text { A2 } & \text { : goat manure } \\ \text { A3 } & \text { : cattle manure }\end{array}$

The second factor was planting medium (ratio of soil and manure weight in polybag). 3 treatments were used in this assay.

$$
\begin{array}{ll}
\text { B1 } & \text { : ratio } 1: 1 \\
\text { B2 } & \text { : ratio } 1: 2 \\
\text { B3 } & \text { : ratio } 1: 3
\end{array}
$$

From these factors, 9 treatments combination were obtained. The treatments were replied 3 times so that 27 experimental units were obtained in this assay. For each experimental unit, there waa 5 plants so that, the total of plant population was 135 plants. The data was analysed by using analysis of variance in 5\% and followed by Duncan's New Multiple Range Test (DNMRT) in 5\%.

The poly bag that was used in this assay sized $40 \mathrm{~cm}$ x $50 \mathrm{~cm}$. The soil that used as planting medium was ultisol soil. The soil was put according the treatment a number $5 \mathrm{~kg}, 6.7 \mathrm{~kg}$ and $7.5 \mathrm{~kg} /$ poly bag and soil was mixed with manure previously. The labelling was conducted before seedlings was planted.

Citronella grass seedlings were obtained from Spice and medicinal crops reserach center, Solok, West Sumatera, Indonesia. The seedlings were free from pest and disease contaminants. All roots that grew in citronella stem were cut by scissor and then the leaves was also cut $5 \mathrm{~cm}$ from midrib. 5 nodes of stem were remained. The stem above 
node was cut $25 \mathrm{~cm}$ in height. The size of citronella grass seedlings was $27 \mathrm{~cm}, 2 \mathrm{~cm}$ in node length and $25 \mathrm{~cm}$ above node.

Application of manure was conducted a week before planting. The manure application was accorded to planting medium weight, $5 \mathrm{~kg}, 3.3 \mathrm{~kg}$ and $2.5 \mathrm{~kg}$. After weight was measured, the manure was put into plastic bag and then the manure was fixed with the soil. The planting medium was incubated for a week before planting.

The planting was conducted after incubation. 1 seedling was planted for each poly bag. The planting was conducted by entering the seedling $5 \mathrm{~cm}$ in depth into the soiland then covered by soil.

The manure application was conducted according to citronella grass cultivation guidence, $150-300 \mathrm{~kg}$ per hectare and applied every year. The application of urea was applied in 1 month after planting with dose of application was $0.75 \mathrm{gram} /$ poly bag. The maintenance was watering, insertion, weeding and pest and disease control. The harvesting was conducted in 5 months after planting. The plants that were ready to be harvested, they had 6-8 leaves in each clump. Commonly, the leaf color was dark green. If the leaves were squeezed, the fragrance is smelled.

The observed variables were number of tillers, number of leaves, plant height, fresh weight and dry weight of plant,dry weight of root, root canopy ratio and rendemen.

\section{Result and discussion:- \\ Number of tillers}

The interaction between manure and planting medium composition did not affect the number of tillers of citronella grass. The difference occured in manure application where cattle manure was the best treatment (Table 1). The number of citronella grass tillers can be seen in Figure 1.The number of tillers were affected by water availability in soil. It stimulated tiller growth by increasing the food storage and nutrients availability. The growth was defined as result of new structural elements. The formation was affected by nutrients availability. The nutrients availabity was closely related to the influence of manure decomposition process. The process was affected microorganism activity in soil [10].

Table 1:-Number of tillers of citronella grass in 4 months after planting

\begin{tabular}{|l|c|c|c|c|}
\hline \multirow{2}{*}{ Manure } & \multicolumn{4}{|c|}{ Planting medium composition } \\
\cline { 2 - 5 } & $1: 1$ & $1: 2$ & $1: 3$ & Average \\
\hline Chicken & 8.06 & 8.36 & 8.20 & $8.21 \mathrm{~b}$ \\
\hline Goat & 7.23 & 7.33 & 7.33 & $1.33 \mathrm{c}$ \\
\hline Cattle & 10.47 & 10.63 & 10.67 & $\mathrm{a}$ \\
\hline Average & 8.58 & 8.77 & & \\
\hline $\begin{array}{l}\text { Coefficient } \\
\text { diversity }=4.57 \%\end{array}$ & & & & \\
\hline
\end{tabular}

The similar uppercase and lower case are different significantly according DNMRT in 5\%

The number of tiller was affected by manure was used. The manure underwent decomposition by microbes and they could improve the soil texture so that it was dense previously became loose. The loose soil was appropriate for citronella grass growth [11]. Cattle manure was the best treatment due to the organic matter content in ultisol soil increased due to the increasing of organic matter from cattle manure [12].

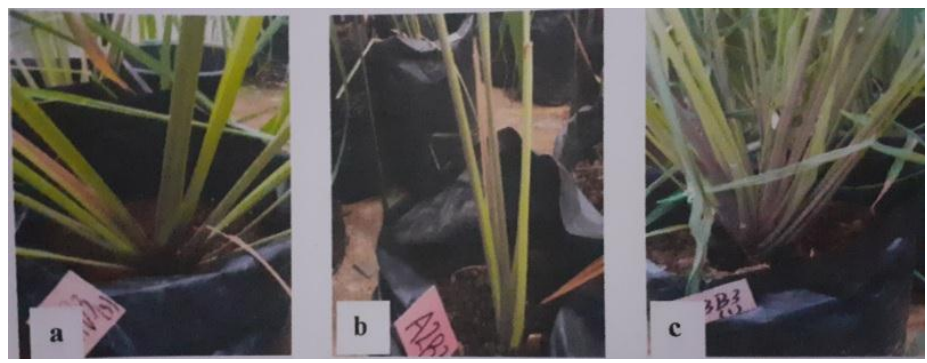

Figure 1:-Number of tiller of citronella grass in 4 monts after planting; a) manure application, b) chicken applicationc. Cattle application 


\section{Number of leaves}

Citronella leaves were part of plant that were used to be extracted to be essential oil. The result showed that the interaction between manure and soil composition did not affect the citronella grass leaves. The number of leaves was only affected by manure application (Table 2).

Table 2:-Number of leaves of citronella grass in 4 months after planting

\begin{tabular}{|l|c|c|c|c|}
\hline \multirow{2}{*}{ Manure } & \multicolumn{4}{c|}{ Planting medium composition } \\
\cline { 2 - 5 } & $1: 1$ & $1: 2$ & $1: 3$ & Average \\
\hline Chicken & 51.22 & 51.96 & 51.44 & $51.52 \mathrm{~b}$ \\
\hline Goat & 42.66 & 43.76 & 41.03 & $42.48 \mathrm{c}$ \\
\hline Cattle & 63.00 & 62.66 & 63.33 & $63.00 \mathrm{a}$ \\
\hline Average & 52.29 & 52.79 & 51.93 & \\
\hline $\begin{array}{l}\text { Coefficient } \\
\text { diversity =5.4\% }\end{array}$ & & & & \\
\hline
\end{tabular}

The similar uppercase and lower case are different significantly according DNMRT in 5\%

The increasing of leaves in line with the increasing of tiller number of citronella grass. Leaves played a role as photosynthesis process occrured. The number of leaves was affected by amount of nitrogen availability. Nitrogen was essential element for plants [13]. Nitrogen built up 1.5\% of plant weight and played role as protein formation. Nitrogen also played a role as protoplasm formation, as cell structure constituent and cell divison [14]. $\mathrm{N}$ content in chicken manure was higher than cattle and goat manure. But number of tiller of chicken manure application was lower so that it affected the leaves number. More number of tiller, number of leaves increased.

Number of leaves in plant afffected the photosynthate that produced by plant. The manure from animal waste that mixed with food waste and urine contained N, P, K. These elements could be used toimprove soil fertile, increased water holding capasity and increased the soil biology [15]. The application of manure was expected to increase nutrients that were required by plant to grow optimally. Moreover, if the dose of manure application was excessive or deficiency, the plant metabolism process was disrupted. Deficiency of $\mathrm{N}$ in soil caused disruption of plant growth due to decreasing of cell divison and chlorosis. $\mathrm{N}$ deficiency in olive plant caused low chlorophyll content and photosynthesis rate decreased [14].

\section{Plant height}

Interaction between manure and soil composition also did not affect the plant height of citronella grass. The plant height was only affected by manure application (Table 3). Chicken and cattle manure caused the soil moree loose than goat manure. Lower manure in composition of planting medium had a similar response to plant height. It described that increasing of manure content in planting medium, it did not affect the plant height of citronella grass.

Table 3:-Plant height of citronella grass in 4 months after planting $(\mathrm{cm})$

\begin{tabular}{|l|c|c|c|c|}
\hline \multirow{2}{*}{ Manure } & \multicolumn{4}{c|}{ Planting medium composition } \\
\cline { 2 - 5 } & $1: 1$ & $1: 2$ & $1: 3$ & Average \\
\hline Chicken & 188.66 & 195.66 & 200.00 & $194.77 \mathrm{a}$ \\
\hline Goat & 180.66 & 184.33 & 185.67 & $183.55 \mathrm{~b}$ \\
\hline Cattle & 194.66 & 191.33 & $195.55 \mathrm{a}$ \\
\hline Average & 187.99 & 190.44 & 195.44 & 1.29 \\
\hline $\begin{array}{l}\text { Coefficient } \\
\text { diversity =5.07\% }\end{array}$ & & & & \\
\hline
\end{tabular}

The similar uppercase and lower case are different significantly according DNMRT in 5\%

Quality of manure significantly affected plant response [16]. Chicken and cattle manure had similar effect to plant height of citronella grass. Chicken manure application showed the best reponse in early stage. It occured due to chicken manure was relatively faster in decomposition and it contained enough nutrient content than other manure. The chicken manure had advantage in nutrient availability. The cattle manure was a good organic matter as basic fertilizer due to it could improve soil fertile, maintained soil structure, increased absorption ability and water holding capacity [12]. 


\section{Fresh weight and dry weight of plant}

Fresh weight and dry weight of citronella plant were not affected by interaction between planting medium composition and manure. These parameters were only affected by manure application (Table 4). The cattle manure was the best manyre to increase the plant fresh weight. Production per clump or fresh weight of plant was $0.59 \mathrm{~kg}$ or $12.04 \mathrm{ton} /$ hectare. According citronella grass characteristic, fresh leaves production of mahapengiri type was 10-12 ton/hectare. In this research, fresh weight was 9.79 ton/hectare. Both results were not siginificantly different.

Table 4:-Fresh weight of citronella grass in 4 months after planting (gram)

\begin{tabular}{|l|c|c|c|c|}
\hline \multirow{2}{*}{ Manure } & \multicolumn{4}{c|}{ Planting medium composition } \\
\cline { 2 - 5 } & $1: 1$ & $1: 2$ & $1: 3$ & Average \\
\hline Chicken & 393.40 & 393.55 & 389.30 & 392.11 \\
\hline Goat & 266.70 & 246.16 & 254.40 & 255.77 \\
\hline Cattle & 489.70 & 490.29 & 479.90 & 386.62 \\
\hline Average & 383.26 & 376.66 & 374.53 & \\
\hline $\begin{array}{l}\text { Coefficient } \\
\text { diversity =3.75\% }\end{array}$ & & & & \\
\hline
\end{tabular}

The similar uppercase and lower case are different significantly according DNMRT in 5\%

The different fertilizer application affected the fresh and dry weight of plant. Dry weight was posstively correlated to number of tiller and number of leaves [17]. More number of tillers and leaves in each clump, they increased fresh weight of plant. Fresh weight was affected by water content and organic matter as nutrients source for photosynthesis. Organic matter contained essential elements for plant [10]. One of essential element was nitrogen (N). N was important element to support plant metabolism through enzymes. Addition of nitrogen in plant increased plant fresh weight. $\mathrm{N}$ positively affected photosynthesis activity and metabolism process of organic compound in plant to support vegetative growth [13].

Fresh weight of plant correlated to dry weight. In dry weight, interaction between manure and planting medium composition also did not affect this parameter. Dry weight was only affected by manure application (Table 5). Dry weight was photosynthesis product after water content was dried from plant fresh weight. This photosynthesis result was affected by environmental factor and water. Optimal environment supported optimal growth. The nutrients that was required should be enough or the dose was optimal. The composition of manure as planting medium was environmental factor. Balance fertilizer dose supported the photosynthesis process. The manure that was added to soil as organic matter for plant could be provided by plant. If the nutrients dissolved, the plant could absorb directly. Water played important role in nutrients absorption by root. If plant underwent drought, the plant could undertake photosynthesis so that the nutrients in soil could not be used by plant [18].

Plant dry material was description of translocation of photosynthesis result to all parts of plant. The plant growth was affected by growth environmental and genetic. Planting medium that contained many organic materials increased plant growth. Organic matter could also increase cation exchange capacity and increased nutrients dissolving in soil such as $\mathrm{N}, \mathrm{P}$ and $\mathrm{K}$ so that the nutrients that required by plant were available and photosynthesis increased [12].

Table 5:-Dry weight of citronella grass in 4 months after planting (gram)

\begin{tabular}{|l|c|c|c|c|}
\hline \multirow{2}{*}{ Manure } & \multicolumn{4}{c|}{ Planting medium composition } \\
\cline { 2 - 5 } & $1: 1$ & $1: 2$ & $1: 3$ & Average \\
\hline Chicken & 150.05 & 146.67 & 147.69 & $148.14 \mathrm{~b}$ \\
\hline Goat & 127.02 & 127.82 & 128.69 & $127.85 \mathrm{c}$ \\
\hline Cattle & 228.96 & 228.80 & 226.32 & $228.03 \mathrm{a}$ \\
\hline Average & 168.68 & 167.76 & 167.57 & \\
\hline $\begin{array}{l}\text { Coefficient } \\
\text { diversity =1.71\% }\end{array}$ & & & & \\
\hline
\end{tabular}

The similar uppercase and lower case are different significantly according DNMRT in 5\%

\section{Root dry weight}

Interaction between planting medium composition and manure affected the root dry weight of citronella grass (Table 6). Goat manure was the best manure for plant root growth. One of goat manure advantage was it contained higher 
K content than chicken and cattle [16]. For root growth, potassium and phosporus were required [19]. Potassium played a important role to support root development so that it increased nutrients absortion by plant.

Table 6:-Root dry weight of citronella grass in 4 months after planting (gram)

\begin{tabular}{|l|c|c|c|}
\hline \multirow{2}{*}{ Manure } & \multicolumn{3}{|c|}{ Planting medium composition } \\
\cline { 2 - 4 } & $1: 1$ & $1: 2$ & $1: 3$ \\
\hline Chicken & $52.50 \mathrm{~b}$ & $53.65 \mathrm{~b}$ & $53.88 \mathrm{~b}$ \\
& $\mathrm{~A}$ & $\mathrm{~A}$ & $\mathrm{~A}$ \\
\hline Goat & $54.21 \mathrm{a}$ & $54.48 \mathrm{a}$ & $54.25 \mathrm{a}$ \\
& $\mathrm{A}$ & $\mathrm{A}$ & $\mathrm{A}$ \\
\hline Cattle & $52.62 \mathrm{c}$ & $52.91 \mathrm{c}$ & $50.75 \mathrm{c}$ \\
& & $\mathrm{A}$ & $\mathrm{B}$ \\
\hline Coefficient of diversity $=1.49 \%$ & & & \\
\hline
\end{tabular}

The similar uppercase and lower case are different significantly according DNMRT in 5\%

Goat manure could increase soil fertility, improved soil structure through soil aggregate, aeration, water holding capacity and cation exchange capacity. Good soil structure caused root could well develope so that width of absorption increased. This condition caused chilli plants well produced [16].

The result also showed that best composition of planting medium was 1:2 with goat manure contained higher potassium content (Table 6). Citronella grass root was classified to fibrous root. The root played a role to absorb nutrients from soil to support plant growth. This caused higher root dry weight or bulk density in goat manure than other manure. High bulk density value indicated the soil had denser soil texture [20]. Water requirement was longer than chicken manure that could absorb water faster. It caused more roots were developed [21].

\section{Root canopy ratio}

Interaction between planting medium and manure did not affect root canopy ratio of citronella grass. The ratio was only affected by manure application (Table 7). Root canopy ratio was observed to study the comparison of growth distribution between canopy and root [22]. High dry and fresh weightof plant but low canopy root ratio, it indicated balance photosynthate partition between root and canopy [23].

Water and nutrients availability that absorbed by plants was a factor that affected plant growth. Root canopy ratio value described amount of photosynthesis result that was accumulated in parts of plant. Moreover, the water capability to absorb water and nutrients also determined growth and development of plant [24].

Table 7:-Root canopy ratio of citronella grass in 4 months after planting

\begin{tabular}{|l|c|c|c|c|}
\hline \multirow{2}{*}{ Manure } & \multicolumn{4}{c|}{ Planting medium composition } \\
\cline { 2 - 5 } & $1: 1$ & $1: 2$ & $1: 3$ & Average \\
\hline Chicken & 1.85 & 1.73 & 1.73 & $1.77 \mathrm{~b}$ \\
\hline Goat & 1.33 & 1.34 & 1.37 & $3.34 \mathrm{~b}$ \\
\hline Cattle & 3.34 & 3.32 & 2.42 & $3.36 \mathrm{a}$ \\
\hline Average & 2.17 & 2.13 & & \\
\hline $\begin{array}{l}\text { Coefficient } \\
\text { diversity =2.65\% }\end{array}$ & & & & \\
\hline
\end{tabular}

The similar uppercase and lower case are different significantly according DNMRT in 5\%

\section{Percentage of rendemen}

Interaction between planting medium composition and manure did not affect percentage of rendemen of citronella grass (Table 8). According the characteristic, Mahapengiri variety had essential rendemen $0.8-1.0 \%$. The result showed that the average percentage of rendemen was 1.0-1.1\%. It was not different significantly from characteristic. The result showed that manure application as organic matter for ultisol soil could increase citronella yield.

Result of rendemen was lower that Sriyadi (2012) [25] that reported citronella grass rendemen for clones G1, G2 and G3 was $0.87 \%, 0.95 \%$ and $0.92 \%$ respectively. The data was supported by previous report that reported citronella grass rendemen was $0.60-0.70 \%$ [3]. Quality of essential oil was affected by many factors such as variety, 
material condition, tools, distillation method product storage. Rendemen was ratio between amount (quantity) and oil that was produced by aromatic plant extraction [26].

Table 8:-Percentage of rendemen of citronella grass in 4 months after planting (\%)

\begin{tabular}{|l|c|c|c|c|}
\hline \multirow{2}{*}{ Manure } & \multicolumn{4}{|c|}{ Planting medium composition } \\
\cline { 2 - 5 } & $1: 1$ & $1: 2$ & $1: 3$ & Average \\
\hline Chicken & 1.1 & 1.0 & 1.0 & 1.0 \\
\hline Goat & 1.1 & 1.1 & 1.1 & 1.1 \\
\hline Cattle & 1.1 & 1.1 & 1.1 & 1.1 \\
\hline Average & 1.1 & 1.1 & 1.0 & \\
\hline
\end{tabular}

\section{Conclusion:-}

The result showed that the ratio 1:2 affected dry weight of root. The beast manure application for growth and yield of citronella grass was $2.5 \mathrm{~kg} /$ poly bag. The best composition of planting medium to cintronella grass was 1:3 for dry weight of root.

\section{References:-}

1. Feriyanto YE, Sipatuhar PJ, Mahfud, Prihatini P. 2013. Essential oil extraction from leaves and stem of citronella grass (Cymbopogon winterianus) using steam distillation method and water in microwave heating. Journal of Pomits Engineering. 2(1): 93-97

2. Astuti A, Putra NN. 2015. Increasing of geraniol content in citronella grass oil and its application as Bio Addaptive Gasoline. J. Bahan Alami Terbarukan. 4(1) : 24-28

3. Syakir M, Gusmani. 2015. Increasing lemon grass herb yield and quality through nitrogen addition. J. Littri. 21 (4): $167-174$

4. Wany A, Jha S, Nigam VK, Pandey DM. 2013. Chemical analysis and therapeutic uses of citronella oil from Cymbopogon winterianus: A short review. International Journal of Advanced Research. 1(6): 504-521

5. Ketaren. 1980. Introduction of essential oil technology. Jakarta : Pustaka Nasional Balai Pustaka

6. Fitriatin BN, Yuniarti A, Turmuktini T, Ruswandi FK. 2014. The effect of phosphate solubilizing microbe producing growth regulators on soil phosphate, growth and yield of maize and fertilizer efficiency on ultisol. Eurasian Journal od Soil Science. 3: 101-107

7. Sutedjo. 2010. Fertilizer and application. Jakarta : Rineka Cipta

8. Daulay MAM. 2016. The effect of planting medium ratio and chicken manure and dose of NPKMg to palm oil plant seedlings in main nursery. Thesis. Faculty of Agriculture. Andalas University. Indonesia

9. Desvita E. 2016. The effect of soil and cattle manure ratio as planting medium to mangosteen seedling growth. Thesis. Faculty of Agriculture. Andalas University. Indonesia

10. Djaenuddin N, Faesal, Soenartiningsih. 2014. Isolation and effectivity examination of several local decomposer in decomposing corn plant waste. Biosfera. 31(2) : 49-55

11. Setiawan, Gusmaini, Nurhayati H. 2018. The response of citronella grass on several NPKMg fertilization in latosol soil type. Bulletin of Research on Spice and Medicinal Crops. 29 (2): 69-78

12. Prasetyo R. 2014. The use of various manure sources as $\mathrm{N}$ source in red chilli cultivation (Capsicum annum L.) in sandy soil. Planta Tropica Journal of Agro Science. 2(2) : 125-132

13. Leghari SJ, Awocho NA, Laghari GM, Laghari AH, Bhabhan GM, Talpur KH, Bhutto TA, Wahocho SA, Lashari AA. 2016. Role of nitrogen for review. Advances in Environmental Biology. 10 (9) : 209-218

14. Olivar VT, Torres OGF, Patino MLD, Nava HS, Martinez AR, Aleman RMM, Aguilar LAV, Tejacal IA. 2014. Role of nitrogen and nutrients in crops nutrition. Journal of Agricultural Science and Technology

15. Pujisiswanto H, Darwin P. 2008. Effect of cattle manure compost to growth and tomato yiedl. Prosiding Seminar Nasional Sains dan teknologi-II. Lampung University. 1-10

16. Hartatik W, Widowati LR. 2010. Manure. Balai Besar Litbang Sumber Daya Lahan Pertanian. Badan Penelitian dan Pengambangan pertanian. $92 \mathrm{p}$.

17. Tuncturk MT, Tuncturk R, Yildrim B, Ciftci V. 2011. Effect of salinity stress on plant fresh weight and nutrient composition of some canola (Brassica napus L.) cultivars. African Journal of Biotechnology. 10(10): 18271832

18. Sujinah, Jamil A. 2016. Mechanism of rice plant response to drought stress and tolerant varieties. Iptek Tanaman Pangan. 11(1): 1-8 
19. Khairunnisa. 2015. Effect of organic and non-organic application and their combination to growth and yield of green mustard. Faculty of Science and Technology. Islam University of Malunana Malik Ibrahim. Malang. Indonesia

20. Cassanova M, Tapia E, Seguel O, Salazar O. 2015. Direct measurement and prediction of bulk density on alluvial soils of central Chile. Chilean Journal of Agricultural Research. 76(1): 105-113

21. Biratu GK, Elias E, Ntawuruhunga P, Nhamo N. 2018. Effect of chicken manure application on cassava biomass and root yields in two agro-ecologies of Zambia. Agriculture. 8(4): 1-15

22. Sinaga R. 2008. The relationship of root canopy ratio and efficiency of water use in elephant and king grass result of water availability decreasing. Sumatera Biology Journal. 3(1) : 29-35

23. Sarief ES. 1986. Fertility and fertilization of farming land. Bandung. Pustaka Nuana. 197 p.

24. Lux A, Rost TL. 2012. Plant root reserach: the apst, the present and the future. Annals of Botany. 110: 201-204

25. Sriyadi. 2012. Characteristic of citronella grass Mahapengiri (Cymbopogon winterianus Jowitt) clone G1, G2 and G3 using chromatograph of spectrometer-gass mass. Faculty of Science. Bogor Agricultural University

26. Yuliani S, Satuhu. 2012. Guidence of essential oil. First publishing. Penebar Swadaya, Jakarta. 